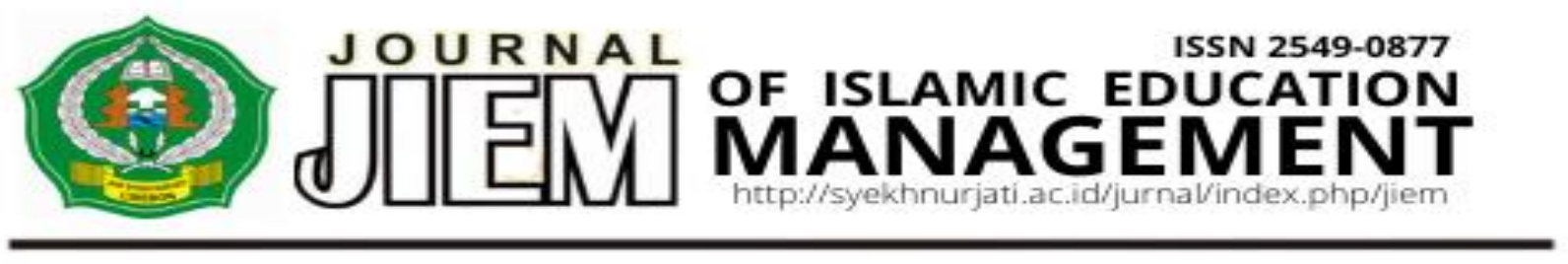

\title{
HUBUNGAN SERTIFIKASI DOSEN DAN GAYA KEPEMIMPINAN REKTOR DENGAN PRODUKTIVITAS KERJA DOSEN \\ RELATIONSHIP BETWEEN LECTURERS' CERTIFICATION, RECTOR'S LEADERSHIP STYLE AND LECTURERS' PRODUCTIVITY
}

\author{
Asep Kurniawan \\ Institut Agama Islam Negeri Syekh Nurjati Cirebon \\ Email: asepkurniawan@syekhnurjati.ac.id
}

\begin{abstract}
ABSTRAK
Semua lembaga pendidikan memerlukan sumber daya manusia yang profesional agar dapat menjalankan fungsinya menuju pencapaian tujuan lembaga pendidikan yang telah ditargetkan. Dinamika produktivitas kerja dosen tergantung pada gaya kepemimpinan pemimpin lembaga pendidikan serta motivasi kerja. Tujuan dari penelitian ini untuk menjelaskan hubungan gaya kepemimpinan, dan sertifikasi dosen terhadap produktivitas kerja dosen IAIN Syekh Nurjati Cirebon. Pendekatan yang digunakan ialah kuantitatif korelasional. Hasil penelitian menunjukkan bahwa, (1) gaya kepemimpinan dan produktivitas kerja dosen berhubungan positif signifikan artinya semakin baik gaya kepemimpinan seorang rektor, maka semakin baik pula produktivitas kerja dosen, (2) motivasi kerja dan produktivitas kerja dosen berhubungan positif signifikan artinya semakin baik motivasi kerja seorang dosen, maka semakin baik pula produktivitas kerja dosen, (3) gaya kepemimpinan dan motivasi kerja dosen berhubungan positif signifikan dengan produktivitas kerja dosen artinya semakin baik gaya kepemimpinan seorang Rektor dan semakin baik motivasi kerja seorang dosen, maka semakin baik pula produktivitas kerja seorang dosen.

Kata kunci: Gaya Kepemimpinan Rektor, Sertifikasi Dosen, Produktivitas Kerja Dosen
\end{abstract}

\begin{abstract}
All educational institutions need professional human resources in order to be able to carry out their functions towards achieving the goals of targeted educational institutions. The dynamics of work productivity of lecturers depend on the leadership style of the leaders of educational institutions and work motivation. The purpose of this study was to explain the relationship of leadership style, and lecturer certification and lecturers' work productivity of State Institute for Islamic Studies Syekh Nurjati Cirebon. The approach was correlational quantitative approach. The results showed that (1)
\end{abstract}


the leadership style and lecturers' work productivity have a positive and significant relationship. It means that the better the leadership style of a rector, the better the work productivity of lecturers. (2) The lecturers' work motivation and work productivity have a positive and significant relationship. It means that the better lecturers' work motivation, the better lecturers' work productivity. (3) The leadership style and lecturers' work motivation have a positive and significant relationship with the lecturers' work productivity. It means that the better style of rector's leadership and the better lectures' work motivation, the better lecturers' productivity.

Keywords: Rector's Leadership Style, Lecturer Certification, Lecturers' Work Productivity

PENDAHULUAN

Semua lembaga pendidikan tinggi semisal

Institut Agama Islam Negeri (IAIN) membutuhkan SDM (Sumber Daya Manusia) yang berkualitas agar bisa melaksanakan fungsinya menuju tercapainya tujuan yang sudah ditetapkan. Rektor sebagai top leader dalam hal ini diharapkan bisa mengembang amanah dengan baik dan mengembangkan diri bersama rekan kerjanya untuk meraih kemajuan institusi pendidikan ini. Tanpa melalui berbagai kemampuan utama seperti komunikasi antar pribadi yang mumpuni, kinerja yang baik, kompetensi dalam pemecahan sejumlah masalah yang mungkin muncul dalam proses manajemen lembaga, rektor IAIN akan menemui hambatan dalam menyampaikan pikiran, saran, usulan, atau ide yang dimilikinya kepada para dosen. Komunikasi di tempat kerja sangat penting untuk membangun dan mempertahankan hubungan kerja yang berkualitas dalam organisasi (Oppong dan Birikorang, 2014: 208; Marques, 2010: 47-58; Thomas, 2009: 287; Somayeh, et al, 2013: 305).

Berpijak hasil penelitian Odine (2015: 1615) menjelaskan bahwa manajemen hanya dapat berkembang dalam prevalensi komunikasi. Sebuah survei tahun 2002 terhadap 1.104 karyawan organisasi di Amerika Serikat menunjukkan bahwa, sementara para manajer menghabiskan 60 hingga 80 persen waktu mereka untuk komunikasi operasional, hanya 17 persen mengatakan manajer mereka berkomunikasi secara efektif. Dengan demikian, setiap langkah konstruktif yang mungkin harus diambil untuk memisahkan bidang yang menghalangi komunikasi yang efektif dalam organisasi bisnis tertentu. Upaya harus dilakukan untuk menciptakan lingkungan bisnis di mana manajer dan staf memperhatikan dengan seksama konseptualisasi dan penyebaran media komunikasi dan pesan yang mereka sampaikan. Karena tujuan yang diinginkan untuk mentransmisikan informasi dari pengirim ke penerima adalah komunikasi yang efektif. Suatu kebenaran bahwa, 60 persen dari upaya public relations perusahaan dikhususkan untuk komunikasi internal, yang merupakan refleksi bahwa komunikasi yang baik adalah jantung dari setiap tempat kerja yang produktif.

Dengan demikian, sudah semestinya pimpinan lembaga pendidikan tinggi semisal 
rektor IAIN yang adalah pemimpin dapat menjadi teladan dan mengayomi bawahan serta mengendalikan fungsi kepemimpinannya. Dosen sebagai bawahan dan bagian dari manajemen lembaga pendidikan seyogyanya merasakan dan mendapatkan kepuasan dalam bekerja agar bisa merealisasikan tujuan lembaga dengan optimal. Produktivitas kerja meliputi aspek lingkungan, psikologis, dan fisik kerja (Vischer, 2007: 175). Perhatian pemimpin kepada bawahannya bisa ikut memastikan tinggi rendahnya kepuasan kerja (Cakmak, Oztekin, dan Karadag, 2015: 29-56; Khan, Asghar, dan Zaheer, 2014: 374-384) mereka termasuk dalam hal ini adalah produktivitas (Surji, 2014, 105-161; Iqbal, Anwar, dan Haider, 2015, 1-6) kerja dosen. Produktivitas kerja yang diterapkan akan menimbulkan perasaan tersendiri bagi para bawahan, bahkan dapat membantu mereka untuk mampu bekerja dengan efektif dan efisien. Kesuksesan lembaga pendidikan tinggi dipengaruhi oleh rektor sebagai pimpinannya.

Selain itu, dalam sejumlah kasus, ada kondisi yang memprihatinkan lembaga pendidikan tinggi yang dapat dilihat dari indisipliner dan kurang profesional para dosennya dalam melaksanakan tugas mengajar. Padahal, berdasarkan sejumlah penelitian (Tahrir, 2010: 145-156; Asvioa, Arpinus, Suharmon, 2017: 16-31; Taştan, et al, 2018: 2353-2366) bahwa disiplin kerja dosen berhubungan secara positif dan signifikan dengan motivasi belajar mahasiswa. Kondisi seperti ini, serta merta dapat mengeser peran dosen sebagai pengembang potensi pribadi mahasiswa. Fakta tersebut tidak bisa dilepaskan dari komunikasi antar pribadi dan pengaruh kinerja rektor dalam melaksanakan kepemimpinannya. Sukses atau tidaknya tujuan lembaga pendidikan tinggi bisa dipengaruhi oleh bagaimana rektor dalam melaksanakan berbagai fungsi manajemen (Sadeli, 2012: 1), yaitu perencanaan, pengorganisasian, penggerakan, dan pengawasan. Program-program yang sudah ditentukan, agar bisa terlaksana dengan baik, maka mesti dilakukan pengawasan pada semua bidang. Untuk bisa menjalankan hal ini, maka dibutuhkan kepemimpinan yang komunikatif dan sejalan dengan kondisi yang ada.

Peningkatan semangat kerja dosen sangat dipengaruhi oleh kinerja rektor. Untuk mendukung kesuksesan kepemimpinan, rektor mesti mempunyai sejumlah keterampilan. Keterampilan ini adalah bekal untuk bisa mengelola pendidikan dengan baik. Keterampilan yang mesti dimiliki ialah keterampilan teknis, keterampilan hubungan manusia, dan keterampilan konseptual (Seyedinejat, Razaghi, dan Dousti, 2014, 3347; Kodikal dan Sucharitha Suresh, 2015: 228).

Kepemimpinan yang efektif bisa bekerja sejalan dengan konteksnya, yakni dapat menyusun visi, membuat gambaran besar, merumuskan tujuan yang jelas, disepakati bersama, dan mengawasi, menganalisis prestasi serta dapat mengembangkan prestasi bawahannya, yakni dengan menyampaikan panduan dan 
pengarahan, membimbing dan melatih serta memberikan feed back. Memimpin dengan memberi keteladanan, yakni dengan berperilaku jujur, mengetahui kesalahan dan kelemahannya sendiri, memperlihatkan komitmen dan keyakinan serta dapat membangun semangat tim. Memberi dukungan, yakni senantiasa mudah diajak bicara dan terbuka, senang memberikan pujian dan semangat, mau menerima saran serta bersedia menjadi jaringan pengaman. Untuk menjadi seorang rektor yang terampil, baik, dan bisa memberikan kepuasan kepada semua elemen institusi pendidikan, terutama dosen adalah bukan sesuatu yang mudah. Hal ini disadari bahwa setiap rektor mempunyai kinerja yang tidak sama, komunikasi antar pribadi yang tidak sama dan keadaan bawahan yang tidak sama pula. Adanya perbedaan sertifikasi, komunikasi antar pribadi, kinerja, dan sebagainya ialah kemungkinan diantara penyebab yang membedakan individu dalam mengimplementasikan pengetahuan teoritis ke dalam berbagai tindakan praktis, memahami konsep, memformulasikan pikiran, menjalin komunikasi, memposisikan dan adaptasi diri di dalam kelompok kerja, serta teori yang erat kaitannya dengan pekerjaan.

Dosen adalah ujung tombak pada pendidikan tinggi di negeri ini tentu mesti bekerja keras untuk membawa dan menghasilkan mahasiswa ke arah kesuksesan, sehingga dapat membangun masyarakat dan bangsa dengan baik. Dosen akan gagal mengembang tugasnya apabila pendidikan dan berbagai pranatanya yang akan mengarahkannya dalam mendidik mahasiswa tidak ada atau tidak berfungsi dengan maksimal. Gaji yang sangat memadai, suasana pendidikan yang kondusif, kurikulum yang tepat, sistem yang baik, pemimpin yang berorientasi kemajuan dan bijaksana, tentu saja sangat diharapkan oleh para pendidik.

Oleh karena itu, keterkaitan antara dosen dan atasannya mesti harmoni dan menghasilkan hakekat mutualisme yang saling memberi andil yang cukup signifikan bagi keberhasilan pendidikan itu sendiri. Dari sinilah selanjutnya dapat melahirkan kepuasan yang tercermin dari dinamisasi dan harmonisasi konstruktif dalam satu lembaga pendidikan.

Pada hakekatnya, pendidikan ialah aktivitas menyiapkan peserta didik melalui latihan, pengajaran, dan bimbingan bagi peranan peserta didik di masa depan. Dalam aktivitas pendidikan tinggi unsur yang sangat menentukan terealisasinya tujuan ialah mahasiswa dan dosen. Kesuksesan mahasiswa sebagai subyek belajar berhubungan dengan proses pribadi dalam menginternalisasi keterampilan, sikap, nilai, dan pengetahuan. Sedangkan kesuksesan dosen sebagai subyek mengajar disamping ditentukan oleh kualitas dosen (Sokoli, 2017: 449) secara personal, tetapi juga ditentukan oleh kuantitas dosen. Dalam hal mutu dosen, ukuran yang dicapai ialah praktek pengabdian pada masyarakat, pengalaman meneliti, pengalaman mengajar, kualifikasi jabatan akademik, dan ijazah terakhir. Perkembangan Institut Agama Islam Negeri yang berperan dalam pengembangan 
ilmu pengetahuan dan teknologi melalui pendidikan dalam pelaksanaan Tri Darma Pendidikan. Semuanya itu berhubungan erat dengan perkembangan kualitas dan produktivitas kerja dosen. Dosen sebagai tenaga pendidik memiliki posisi strategis. Dia memiliki pengaruh langsung terhadap proses belajar mahasiswa. Pendidikan tinggi tidak hanya menyampaikan materi kuliah kepada mahasiswa namun pula mesti merupakan pusat penelitian (Nulhaqim, et al, 2016: 198). Siklus perkembangan ilmu pengetahuan semakin singkat, maka dari itu proses belajar yang tidak didukung oleh riset akan kehilangan artinya.

Dalam hal ini mesti ada sinergi antara pengajaran dan penelitian. Dosen yang hanya mengajar saja tanpa meneliti, maka lambat laun akan ketinggalan zaman dan tersisihkan dari tugas profesinya. Antara mengajar dan penelitian adalah siklus yang teratur. Pada suatu saat seorang dosen diamanatkan untuk mengajar, pada suatu saat yang lain diamanatkan untuk meneliti atau memasuki dunia industri. Keadaan ini hanya bisa terjadi jika perguruan tinggi dan pihak swasta memiliki keterkaitan yang erat.

Pada konteks ini tukar menukar informasi penelitian dan kerjasama regional dan internasional di dalam proses pembelajaran adalah hal keniscayaan bagi pendidikan tinggi abad 21 (Rahzianta dan Hidayat, 2016: 1128-1137). Melalui kemajuan teknologi komunikasi, kerjasama ini bisa dilakukan bahkan tidak saja untuk pengembangan kompetensi dosen, namun pula untuk meningkatkan proses belajar mahasiswa. Kepemimpinan yang efektif bisa direalisasikan melalui pendekatan perilaku (Soliha dan Hersugondo, 2008: 88). Pendekatan perilaku kepemimpinan memfokuskan kepada fungsi yang dilaksanakan pemimpin. Pertama, fungsi yang berkaitan dengan pemecahan masalah. Kedua, fungsi pemeliharaan sosial atau kelompok. Sedangkan pendekatan yang kedua mengenai perilaku kepemimpinan memfokuskan pada gaya kepemimpinan dalam kaitannya dengan bawahan. Ditinjau dari aspek orientasi ke masa depan, ada dua gaya kepemimpinan. Pertama, gaya dengan orientasi tugas, kedua, gaya dengan orientasi orang.

Sertifikasi dosen adalah bagian yang mendasar dalam aktivitas manajemen perguruan tinggi karena sertifikasi dosen adalah kunci produktivitas kerja. Sementara itu, produktivitas kerja ialah tujuan utama dari suatu manajemen. Fungsi sertifikasi ialah untuk mengupayakan agar orang-orang dapat bekerja untuk mancapai tujuan dengan senang hati. Sertifikasi pada seseorang ialah kekuatan pendorong yang akan merealisasikan suatu perilaku untuk pencapaian tujuan organisasi. Sertifikasi dosen sebagian dipengaruhi oleh profesionalisme, sedangkan profesionalisme senantiasa harus ditingkatkan dari waktu ke waktu.

Disamping itu, produktivitas kerja yang didorong oleh sertifikasi (Kodri, Fitriani, Juliantina, 2018: 9) dosen (Muhardi dan Nurcahyono, 2011: 99) dan kepemimpinan efektif (Purwanto, 2015: 47) yang positif akan mengarahkan organisasi pada pencapaian tujuan. Tinggi rendahnya produktivitas kerja 
faktanya banyak dipengaruhi oleh sejumlah faktor, mulai dari teknologi, manajemen, disiplin bawahan, dan sampai pada sikap. Untuk itu, produktivitas kerja harus ditingkatkan melalui manajemen terpadu meliputi latihan, pendidikan, perbaikan sistem, dan pembentukan sikap mental. Untuk bisa mencapai efisiensi yang tinggi dan produktivitas kerja harus dilakukan penataan ulang, khususnya penataan SDM (Sumber Daya Manusia). Orientasi SDM seyogyanya tidak hanya bekerja untuk mencari penghasilan akan tetapi untuk mengembangkan diri. Oleh karena itu, keinginan meraih prestasi yang tinggi dapat mengarahkannya kepada usaha peningkatan mutu dan produktivitas kerja.

Produktivitas kerja dosen adalah faktor yang amat mempengaruhi keberhasilan suatu institusi pendidikan tinggi dalam menjalankan misi. Oleh sebab itu, pengembangan dosen dan pengukuran produktivitas kerjanya adalah faktor yang sangat penting. Pengukuran dan penilaian produktivitas kerja dosen ditentukan oleh besar kecilnya lembaga pendidikan tinggi khususnya menjadi fokus adalah siapa atau masuk ke dalam kategori pengukuran yang mana, yang operasional, manajerial, atau strategi. Akan tetapi, untuk seluruh ukuran lembaga pendidikan, semua ketua jurusan mesti melaksanakan pengukuran dan penilaian terhadap produktivitas kerja dosen. Pengukuran dan penilaian seyoyanya dilaksanakan secara kualitatif dan sebisa mungkin secara kuantitatif pula, sebab pengukuran dan penilaian mungkin ada kaitannya dengan pemberian insentif, atau bentuk penghargaan lain.

IAIN Syekh Nurjati adalah Perguruan Tinggi Islam Negeri yang mengelola berbagai jurusan yang sejalan dengan perkembangan tuntutan zaman dan kebutuhan masyarakat. Perkembangan perguruan tinggi ini cukup dinamis, terbukti dari pengajuan alih status akhir-akhir ini menuju universitas. Hal ini didorong oleh semangat kerja yang tinggi segenap civitas akademiknya terutama para dosen, sebab berkaitan langsung dengan mutu SDM. Sementara itu, produktivitas kerja sangat tergantung pada sertifikasi dosen. Atas dasar ini, dalam hal ini pimpinan mesertifikasi dosen para dosen bagi pencapaian produktivitas kerjanya untuk tercapainya Perguruan Tinggi Islam Negeri yang unggul. Berangkat dari uraian tersebut penulis tertarik untuk merlakukan penelitian tentang Hubungan Sertifikasi dosen dan Gaya Kepemimpinan dengan Produktivitas Kerja Dosen IAIN Syekh Nurjati.

\section{METODE}

Pendekatan yang dalam penelitian ini ialah pendekatan kuantitatif korelasional untuk mencari apakah terdapat hubungan antara dua variabel atau lebih dan sejauhmana hubungan antar variabel yang diteliti (Kurniawan, 2018: 38). Responden penelitian terdiri dari 90 dosen yang teridiri dari 35 orang dosen fakultas Ilmu Tarbiyah dan Keguruan, 30 dosen fakultas Syariah Ekonomi Islam, dan 25 dosen fakultas Ushuludin Adab dan Dakwah. Penelitian ini memakai kuesioner sebagai instrumen utama pengumpul data 
didukung oleh instrumem wawancara, pengamatan, dokumentasi, dan tes. Teknik pengolahan data dilakukan melalui edit, coding, dan tabulating. Uji instrumen meliputi uji validitas dan uji reliabilitas. Tehnik analisis data ditempuh dengan analisis deskriptif dan analisis regresi linier berganda uji $f$, uji $t$ dan mencari besar koefisien determinasi atau R2 adjusted. Untuk memudahkan perhitungan, penulis memakai program SPSS (Statistical Package for Sosial Science) for Windows versi 24. Uji f dimaksudkan untuk menguji sejumlah variabel bebas secara bersama-sama terhadap variabel terikat. Sedangkan Uji t digunakan untuk menemukan hubungan antara variabel gaya kepemimpinan dan sertifikasi dosen dengan produktivitas kerja. Dalam rangka memperoleh parameter-parameter estimasi dari model dinamis, maka dalam hal ini penulisa menggunakan metode penaksiran Ordinary Least Square (OLS). Penggunaan metode ini diiringi dengan sejumlah asumsi yang melandasinya. Sejumlah asumsi tersebut, yakni: normalitas, multikolinearitas, homoskedastisitas, dan autokorelasi.

\section{HASIL DAN PEMBAHASAN}

\section{Sertifikasi Dosen}

Sertifikasi dosen merupakan aktivitas pemberian sertifikat pendidik terhadap dosen. Program ini adalah kegiatan meningkatkan kualitas pendidikan nasional, dan meningkatkan kesejahteraan dosen, dengan memotivasi dosen untuk secara berkesinambungan meningkatkan profesionalismenya. Sertifikat pendidik ini diserahkan kepada dosen melalui proses sertifikasi ialah bukti formal legitimasi terhadap dosen sebagai sumber daya manusia yang profesional pada strata pendidikan tinggi (Dirjen Dikti, 2008: ii).

Sertifikasi dosen adalah program yang dilaksanakan berpijak pada UU Nomor 20 Tahun 2003 mengenai Sistem Pendidikan Nasional, UU No. 14 Tahun 2005 mengenai Guru dan Dosen, dan Peraturan Pemerintah R.I. Nomor 37 Tahun 2009 mengenai Dosen dan Peraturan Menteri Pendidikan Nasional RI No. 47 Tahun 2009 mengenai Sertifikasi Pendidik Untuk Dosen. Proses penilaian akhir portofolio dilaksanakan oleh sejumlah asesor, yang diusulkan oleh perguruan tinggi pelaksana sertifikasi dosen sesudah mengikuti pembekalan sertifikasi, dan memperoleh pengesahan dari Direktorat Jenderal Pendidikan Tinggi (Dirjen Dikti, 2008: ii).

Sertifikasi dosen ialah kebijakan yang sangat strategis, sebab tujuan dan langkah melaksanakan sertifikasi dosen untuk meningkatkan mutu dosen, mempunyai kompetensi, mengangkat wibawa dan harkat dosen sehingga dosen lebih dihargai dan untuk meningkatkan mutu pendidikan di Indonesia. Akan tetapi masih ada persoalan yang berhubungan dengan pemberian sertifikasi dosen di antaranya masih ada dosen yang belum disertifikasi belum maksimal melakukan tugas-tugasnya. Oleh karena itu, tunjangan sertifikasi mempunyai hubungan timbal balik dengan kinerja dosen. Tunjangan sertifikasi yang diberikan kepada dosen bisa meningkatkan kinerjanya. 
Alat pengumpulan data yang dipakai guna mengukur sertifikasi dosen ialah angket yang meliputi 16 butir yang setiap butirnya memiliki 5 pilihan alternatif jawaban dengan rentang skor 1-5. Skor harapan terendah adalah 16 dan skor harapan tertinggi adalah 80. Berpijak pada skor total harapan ini bisa ditetapkan internal skor setiap kelas yang mendeskripsikan sertifikasi dosen yang meliputi dari 5 tingkatan, yaitu sangat tinggi, tinggi, sedang, rendah, dan sangat rendah.

Data mengenai sertifikasi dosen yang penulis kumpulkan dari sejumlah 85 responden secara kuantitatif memperlihatkan bahwa skor total setidaknya 16 dan skor total maksimal adalah 80. Rentang jumlah skor maksimal dengan skor total minimal yang mungkin didapatkan, yaitu $80-16+1=65$. Interval kelas atau tingkat variabel sejumlah 5, maka lebar kelas interval ialah $65: 5=13$. Gaya Kepemimpinan

Alat pengumpulan data yang dipakai guna mengukur gaya kepemimpinan ialah angket yang meliputi 13 butir. Setiap butir memiliki 5 buah pilihan jawaban dengan rentang skor 1-5. Skor harapan terendah adalah 13 dan skor harapan tertinggi adalah 65. Berpijak pada skor total harapan ini, maka bisa ditetapkan internal skor setiap kelas yang mendeskripsikan gaya kepemimpinan meliputi 5 tingkatan, yaitu sangat tinggi, tinggi, sedang, rendah, dan sangat rendah. Data mengenai gaya kepemimpinan yang dapat dikumpulkan dari sejumlah 85 responden secara kuantitatif memperlihatkan bahwa skor total minimal ialah 13 dan skor total maksimal ialah 65. Rentang jumlah skor maksimal dengan skor total minimal yang mungkin didapatkan ialah $65-13+1=51$. Tingkat variabel atau interval kelas sejumlah 5 maka lebar kelas interval ialah $51: 5=11$. Produktivitas Kerja

Alat pengumpulan data yang dipakai guna mengukur produktivitas kerja, yaitu angket yang meliputi 12 butir. Setiap butir memiliki 5 buah pilihan jawaban dengan rentang skor 1-5. Skor harapan terendah ialah 12 dan skor harapan tertinggi ialah 60 . Berpijak pada skor total harapan ini bisa ditetapkan internal skor setiap kelas yang mendeskripsikan produktivitas kerja meliputi 5 tingkatan, yaitu sangat tinggi, tinggi, sedang, rendah, dan sangat rendah.

Data mengenai produktivitas kerja yang berhasil penulis kumpulkan dari sejumlah 85 responden secara kuantitatif memperlihatkan bahwa skor total minimal 12 dan skor total maksimal ialah 60. Rentang jumlah skor maksimal dengan skor total minimal yang mungkin didapatkan ialah $60-12+1=49$. Interval kelas atau tingkat variabel sejumlah 5, maka lebar kelas interval ialah $49: 5=10$.

Hipotesis yang diuji dalam penelitian ini ialah hipotesis nol yang menjelaskan secara parsial tidak ada hubungan antara variabel sertifikasi dosen dan gaya kepemimpinan dengan produktivitas kerja dosen IAIN Syekh Nurjati Cirebon dan ada hubungan antara variabel sertifikasi dosen dan gaya kepemimpinan dengan produktivitas kerja IAIN Syekh Nurjati Cirebon sebab perhitungan memakai bantuan program SPSS for Windows versi 24, maka uji hipotesis dilaksanakan melalui perbandingan 
probabilitas yang didapatkan dengan tingkat signifikansi 0,05 dengan cara pengambilan keputusan, yaitu apabila probabilitas $<0,05$ Ha diterima. Apabila probabilitas > 0,05 Ho ditolak.

Dalam rangka menerima $\mathrm{Ha}$ dan menolak Ho, pengujian ini ditempuh dengan memperhitungkan nilai probabilitas $f_{\text {hitung. }}$. Apabila (probabilitas Sig) $\leq 0,05$, maka Ho ditolak. Jika ditolak, artinya semua variabel bebas memiliki hubungan yang signifikan terhadap variabel terikatnya.

Tabel hasil analisis regresi di bawah ini menerangkan bahwa variabel sertifikasi dosen dan gaya kepemimpinan berkaitan secara simultan dengan produktivitas kerja yang diperlihatkan oleh $f_{\text {hitung }}$ sejumlah 103,512 dengan probabilitas (Sig) sebesar 0,000 (0 \%) $<0,05$. Jadi taraf kebenaran model regresi yang terbentuk sejumlah $100 \%$. Dari hasil uji hipotesis yang ditempuh maka didapatkan:

Tabel 1. Hasil Uji Hipotesis

\begin{tabular}{|c|l|l|c|}
\hline No & Hipotesis Ho \& Ha & \multicolumn{1}{|c|}{ Nilai } & Status \\
\hline 1 & $\begin{array}{l}\text { Tidak terdapat } \\
\text { hubungan } \\
\text { Ada hubungan }\end{array}$ & $\begin{array}{l}\text { Probblts }=0,00 \\
\text { Sig=0,05 }\end{array}$ & $\begin{array}{l}\text { Ho ditolak } \\
\text { Ha diterima }\end{array}$ \\
\hline 2 & $\begin{array}{l}\text { Tidak terdapat } \\
\text { hubungan } \\
\text { Ada hubungan }\end{array}$ & $\begin{array}{l}\text { Probblts }=0,00 \\
\text { Sig=0,05 }\end{array}$ & $\begin{array}{l}\text { Ho ditolak } \\
\text { Ha diterima }\end{array}$ \\
\hline 3 & $\begin{array}{l}\text { Tidak terdapat } \\
\text { hubungan } \\
\text { Ada hubungan }\end{array}$ & $\begin{array}{l}\text { Probblts }=0,00 \\
\text { Sig=0,05 }\end{array}$ & $\begin{array}{l}\text { Ho ditolak } \\
\text { Ha diterima }\end{array}$ \\
\hline
\end{tabular}

Hipotesis hubungan antara variabel

gaya kepemimpinan dengan produktivitas kerja dosen IAIN Syekh Nurjati Cirebon. Berpijak pada tabel tersebut pengujian hipotesis nol (0) pertama nilai probabilitas sejumlah 0,00 nilai ini lebih kecil dari signifikansi yang ditentukan, yaitu sejumlah $0,05(0,00<0,05)$. Oleh karena itu, pengujian memperlihatkan Ha diterima dan Ho ditolak, maka hasil ini bermakna bahwa gaya kepemimpinan berhubungan secara signifikan dengan produktivitas kerja dosen IAIN Syekh Nurjati Cirebon.

Hipotesis hubungan antara variabel sertifikasi dosen dengan produktivitas kerja dosen IAIN Syekh Nurjati Cirebon. Untuk hipotesis kedua nilai probabilitas sejumlah 0,00 nilai ini lebih kecil dari signifikansi yang sudah ditentukan, yaitu sebesar 0,05 $(0,00<$ 0,05). Oleh karena itu, pengujian memperlihatkan Ha diterima dan Ho ditolak. Hasil ini menunjukkan bahwa sertifikasi dosen berhubungan secara signifikan dengan produktivitas kerja dosen IAIN Syekh Nurjati Cirebon.

Hipotesis hubungan antara variabel gaya kepemimpinan dan sertifikasi dosen dengan produktivitas kerja IAIN Syekh Nurjati Cirebon. Sedangkan untuk hipotesis ketiga dilaksanakan dengan memperhatikan probabilitas uji serempak uji f didapatkan nilai probabilitas yang lebih kecil dari signifikansi yang sudah ditentukan $0,00<$ 0,05 ini memperlihatkan bahwa ada hubungan antara gaya kepemimpinan rektor dan sertifikasi dosen dengan produktivitas kerja dosen IAIN Syekh Nurjati Cirebon.

Tabel 2. Hasil Uji Regresi Coefficiena ts

\begin{tabular}{|c|c|c|c|c|c|c|c|c|c|c|}
\hline \multirow[t]{2}{*}{ Mod } & \multicolumn{2}{|c|}{$\begin{array}{l}\text { nstandardize } \\
\text { Coefficients }\end{array}$} & $\begin{array}{l}\text { andar } \\
\text { diz } \\
\text { oeffici } \\
\text { ent }\end{array}$ & \multirow[t]{2}{*}{$\mathrm{t}$} & \multirow[t]{2}{*}{ Sig. } & \multicolumn{3}{|c|}{ Correlations } & \multicolumn{2}{|c|}{$\begin{array}{c}\text { linearity } \\
\text { Statis }\end{array}$} \\
\hline & B & td. Err & Beta & & & $\begin{array}{l}\text { ero- } \\
\text { ord }\end{array}$ & $\begin{array}{c}\text { Partia } \\
1\end{array}$ & Part & $\begin{array}{c}\text { oleran } \\
\mathrm{c}\end{array}$ & VIF \\
\hline \multirow{3}{*}{$\begin{array}{l}1(\text { Con } \\
\text { st } \\
\text { X1 X2 } 2\end{array}$} & 2.243 & 1.585 & & 1.415 & .161 & & & & & \\
\hline & .675 & .074 & .619 & 9.081 & .000 & .793 & .708 & .534 & .745 & 1.343 \\
\hline & .326 & .065 & .344 & 5.042 & .000 & .656 & .486 & .297 & .745 & 1.343 \\
\hline
\end{tabular}

a. Dependent Variable: $Y$ 
Tabel 3. Hasil Uji Simultan ANOVA

\begin{tabular}{|c|c|c|c|c|c|}
\hline Model & $\begin{array}{l}\text { Sum of } \\
\text { Squares }\end{array}$ & $\mathrm{df}$ & $\begin{array}{l}\text { Mean } \\
\text { Square }\end{array}$ & $\mathrm{F}$ & Sig. \\
\hline 1 Regressio & n 998.083 & 2 & \multirow{3}{*}{$\begin{array}{l}499.041 \\
4.821\end{array}$} & \multirow[t]{3}{*}{103.512} & \multirow[t]{3}{*}{$.000^{\mathrm{a}}$} \\
\hline Residual & 395.329 & 82 & & & \\
\hline Total & 393.412 & 84 & & & \\
\hline
\end{tabular}

Berpijak pada tabel tersebut, maka didapatkan persamaan garis regresi sebagai berikut: produktivitas kerja $(\mathrm{y})-2,243+0$, $675 \times 1+0,326 \times 2$, standar kesalahan persamaan regresi sejumlah 1, 585 untuk beta nol (0) standar error persamaan regresi sejumlah 0,074 untuk variabel gaya kepemimpinan rektor dan 0,065 bagi variabel sertifikasi dosen. Adapun nilai $\mathrm{t}$ test bagi variabel gaya kepemimpinan rektor sejumlah 9, 081 dengan nilai $\mathrm{p}=0,00$. Untuk variabel sertifikasi dosen nilai t test sejumlah 5, 042 dengan nilai $\mathrm{p}=0,00$. Hal ini bermakna bahwa gaya kepemimpinan rektor ataupun sertifikasi dosen secara bersamaan berhubungan secara signifikan dengan produktivitas kerja dosen IAIN Syekh Nurjati Cirebon. Dari persamaan regresi ini ditemukan bahwa hubungan gaya kepemimpinan rektor lebih tinggi, yaitu sejumlah 0,675 dari pada sertifikasi dosen, yaitu sebesar 0,326 dengan produktivitas kerja dosen. Dari persamaan regresi di atas bisa dimaknai hubungan setiap variabel bebas (x), yaitu (1) satu angka kenaikan nilai variabel gaya kepemimpinan rektor mengakibatkan kenaikan nilai variabel produktivitas kerja dosen sejumlah 0,675 . (2) Satu angka kenaikan nilai variabel sertifikasi dosen mengakibatkan kenaikan nilai variabel produktivitas kerja dosen sejumlah 0, 326. (3)
Tanpa ada variabel gaya kepemimpinan rektor dan sertifikasi dosen keadaan produktivitas kerja dosen IAIN Syekh Nurjati Cirebon turun sejumlah - 2, 243.

Sejalan dengan penyajian hasil pengujian hipotesis nol tersebut ditunjukkan dengan terdapatnya 3 hipotesis nol (0) ditolak (artinya tidak ada hubungan). Oleh karena itu, bisa difahami bahwa ada tiga buah jalur hubungan yang berhasil mendukung atau membuktikan teori yang dipakai dalam memformulasikan hipotesis alternatif. Adapun kuatnya hubungan kedua variabel bebas dengan variabel terikat dapat diperhatikan pada tabel.

Tabel 4. Hasil Uji Keakuratan Model Model Summary

\begin{tabular}{|l|c|c|c|l|l|}
\hline $\begin{array}{l}\text { Mo } \\
\text { del }\end{array}$ & $\mathrm{R}$ & $\begin{array}{c}\mathrm{R} \\
\text { Square }\end{array}$ & $\begin{array}{c}\text { Adjusted } \\
\text { R Square }\end{array}$ & $\begin{array}{l}\text { Std. Error of } \\
\text { the Estimate }\end{array}$ & $\begin{array}{l}\text { Durbin- } \\
\text { Watson }\end{array}$ \\
\hline 1 & $.846^{\mathrm{a}}$ & .716 .709 & 2.19570 & 1.672 \\
\hline
\end{tabular}

a. Predictors: (Constant), X2, X1

b. Dependent Variable: Y

Kesimpulan yang bisa diambil berpijak pada hasil pengujian hipotesis tersebut ialah yang direfresentasikan oleh variabel gaya kepemimpinan rektor dan sertifikasi dosen berhubungan secara simultan (serentak) dengan produktivitas kerja dosen. Secara parsial gaya kepemimpinan rektor dan sertifikasi dosen berhubungan secara signifikan dengan produktivitas kerja dosen.

Sesudah dilaksanakan uji model, maka langkah berikutnya ialah dilaksanakan perhitungan korelasi guna mengukur keakuratan garis regresi dalam menerangkan variasi nilai variabel bebas. Hasil analisis korelasi yang didapatkan dari output regresi hubungan yang direfresentasikan oleh 
variabel gaya kepemimpinan rektor dan sertifikasi dosen dengan produktivitas kerja dosen didapatkan nilai R-squared $(\mathrm{R} 2)=$ 0,716. Angka ini memperlihatkan bahwa variasi nilai produktivitas kerja dosen yang bisa diterangkan oleh persamaan regresi yang didapatkan sejumlah $71,6 \%$, sementara itu sisanya, yakni $28,4 \%$ dijelaskan oleh variabel lain di luar persamaan model. Sedangkan R sebesar 0,846, bermakna hubungan antara variabel gaya kepemimpinan rektor dan sertifikasi dosen dengan produktivitas kerja dosen ialah cukup kuat ( $\mathrm{R}$ di atas 0,05).

Sedangkan untuk mengungkap variabel yang paling menonjol mempengaruhi produktivitas kerja dosen bisa ditinjau dari nilai korelasi parsial setiap variabel dengan produktivitas kerja dosen. Dari output perhitungan software SPSS for Windows versi 24 di atas memperlihatkan bahwa nilai korelasi parsial tertinggi sejumlah 70,8 \% terjadi antara variabel gaya kepemimpinan rektor dengan produktivitas kerja dosen.

Dari hasil analisis bisa disebutkan bahwa terdapat hubungan signifikan antara gaya kepemimpinan rektor dengan produktivitas kerja dosen IAIN Syekh Nurjati Cirebon. Apabila ditinjau dari koefisiennya, maka gaya kepemimpinan rektor mempunyai hubungan yang cukup besar terhadap produktivitas kerja dosen IAIN Syekh Nurjati Cirebon. Oleh karena itu, bisa difahami bahwa makin besar/tinggi hubungan gaya kepemimpinan rektor, maka makin besar/tinggi juga produktivitas kerja dosen IAIN Syekh Nurjati Cirebon.
Hasil penelitian ini menegaskan pendapat bahwa kepemimpinan adalah hubungan di mana satu orang, atau pemimpin memengaruhi orang lain untuk bekerja bersama secara sukarela pada tugas terkait untuk mencapai apa yang diinginkan oleh pemimpin (Raju dan Parthasarathy, 2009: 119; Hao dan Yazdanifard, 2015: 1). Gaya kepemimpinan yang efektif dapat meningkatkan produktivitas kerja dosen sehingga dapat mudah dalam mencapai tujuan organisasi (Abba, et al, 2016: 56). Gaya kepemimpinan yang menggairahkan dosen adalah sumber disiplin, modal, dan motivasi dalam menunaikan beban kerja yang menjadi tanggungjawab dosen. Dengan demikian sebaliknya, ketidakefektifan seorang pemimpin dalam memimpin dosen akan memiliki akibat negatif bagi produktivitas kerja dosen.

Produktivitas kerja diakibatkan oleh sejumlah faktor baik yang berkaitan dengan lingkungan dan iklim organisasi (Karyana, 2012: 67; Hardjana, 2006: 4) serta berbagai kebijakan yang berlaku. Faktor gaya kepemimpinan rektor yang efektif dapat mengembangkan produktivitas kerja dosen. Gaya kepemimpinan rektor yang menyenangkan dosen adalah sumber disiplin, sumber modal, dan motivasi dosen dalam melakukan beban kerja yang menjadi tanggungjawab mereka. Demikian pula ketidak efektifan seorang pemimpin dalam mengelola/memimpin dosen akan memiliki akibat rendah/buruk terhadap produktivitas kerja dosen. 
Tanggapan yang sama juga diutarakan oleh Mahayreh, et al (2016: 27) bahwa gaya kepemimpinan ialah usaha memakai banyak pengaruh secara sukarela untuk mendorong anggota organisasi untuk merealisasikan tujuan tertentu. Pada dasarnya mendorong dosen bermakna harus dilaksanakan sebagai aktivitas pendorong anggota organisasi guna melaksanakan kegiatan atau pekerjaan tertentu yang tidak mengarah dan memaksa pada tujuan. Selanjutnya menurut Thoha (2013: 49) bahwa gaya kepemimpinan adalah norma perilaku yang dipakai oleh seseorang ketika ia mencoba mempengaruhi perilaku orang lain sebagaimana yang dia lihat.

Dari hasil penelitian ini bisa dijelaskan bahwa gaya kepemimpinan seorang pemimpin mempunyai peranan yang penting dalam meningkatkan produktivitas kerja dosen-dosen IAIN Syekh Nurjati Cirebon. Dari hasil analisis bisa diuraikan bahwa ada hubungan signifikan sertifikasi dosen dengan produktivitas kerja dosen IAIN Syekh Nurjati Cirebon. Apabila ditinjau dari koefisiennya, maka sertifikasi dosen mempunyai hubungan yang cukup besar terhadap produktivitas kerja dosen IAIN Syekh Nurjati Cirebon. Oleh karena itu, bisa disimpulkan bahwa makin besar atau tinggi hubungan sertifikasi dosen, maka makin besar/tinggi pula produktivitas kerja dosen.

Ungkapan yang sama juga diungkapkan oleh French dan Raven, sebagaimana dikutip Stoner, Freemen, dan Gilbert, sertifikasi dosen ialah sesuatu yang mendorong seseorang untuk memperlihatkan perilaku tertentu. Hal ini sejalan dengan yang disampaikan oleh Pandji Anoraga (2006: 19), faktor yang mempengaruhi kinerja ialah imbalan, gaji, atau kompensasi. Faktor ini meskipun pada dasarnya tidak menempati urutan paling tinggi, namun masih merupakan faktor yang dianggap mudah mempengaruhi kegairahan dan ketenangan kerja guru. Dengan sertifikasi ini dosen akan melalui sejumlah persyaratan dan proses tertentu untuk memperoleh sertifikat sebagai pendidik profesional. Undang-undang guru dan dosen menjelaskan bahwa sertifikasi adalah sebagai bagian dari upaya peningkatan kualitas dosen dan peningkatan kesejahteraannya. Dosen yang sudah bersertifikat berhak memperoleh reward (imbalan), yaitu tunjangan profesi dari pemerintah sejumlah satu kali gaji pokok. Sertifikasi ini mesti dipertahankan oleh dosen melalui peningkatan kinerjanya.

Kenapa sertifikasi dosen mesti diberikan oleh pimpinan kepada bawahannya? Hal tersebut karena (1) pimpinan membagikan pekerjaannya kepada bawahan untuk dilakukan dengan baik, (2) ada bawahan yang dapat melakukan pekerjaannya, namun dia malas atau kurang bergairah mengerjakannya, (3) untuk meningkatkan dan memelihara kegairahan dan semangat kerja bawahan dalam melaksanakan perkejaan, (4) untuk memberi kepuasan dan penghargaan kerja kepada bawahannya.

Pemimpin atau manajer dalam memberikan dosen ini mesti menyadari bahwa bawahan dapat bekerja keras dengan harapan, dia akan bisa memenuhi keinginankeinginan dan kebutuhan dari hasil 
pekerjaannya. Keinginan-keinginan dan kebutuhan itu ialah (1) hasrat untuk hidup. Keinginan untuk hidup adalah keinginan utama dari semua manusia, orang bekerja agar bisa makan untuk melanjutkan hidupnya, (2) hasrat untuk mempunyai sesuatu adalah keinginan manusia sebagai penyebab mengapa manusia mau bekerja, (3) hasrat terhadap kekuasaan adalah keinginan setahap di atas keinginan untuk memiliki. Hal ini memotivasi orang mau bekerja, (4) hasrat terhadap pengakuan adalah tahap terakhir dari kebutuhan dan juga memotivasi orang untuk bekerja (Soetrisno, 2017: 117-118).

Oleh karena itu, jelas bagi kita bahwa semua orang memiliki keinginan tertentu dan menginginkan kepuasan dari hasil pekerjaannya. Menurut Maslow, keinginan dan kebutuhan yang dipuaskan dengan bekerja itu ialah (1) kebutuhan fisiologis, yakni kebutuhan tingkat pertama yang paling rendah yang mesti dipenuhi dan dipuaskan oleh karyawan sebelum dirinya mencapai kebutuhan pada tingkat yang lebih tinggi. Kebutuhan ini terdiri dari pernapasan, makan, minum, dan kebutuhan lain yang bersifat biologis seperti seks dan tidur. (2) Kebutuhan keamanan adalah kebutuhan tingkat kedua yang harus dipenuhi sesudah kebutuhan tingkat pertama terpenuhi dan terpuaskan. Kebutuhan-kebutuhan yang termasuk dalam kebutuhan keamanan ialah bebas dari rasa takut dan ancaman, perlindungan, ketergantungan, dan kestabilan. Termasuk juga kebutuhan dalam mengikuti peraturan dan tata tertib secara struktural.

Kebutuhan sosial, yakni kebutuhan untuk berhubungan dengan orang lain. Pada saat ini individu akan merasa sangat kesepian dan terisolasi dari pergaulan. Individu akan memerlukan teman dan perhatian dari seseorang. (4) Kebutuhan harga diri ialah kebutuhan terhadap kekuasaan, pemenuhan diri, berprestasi, kekuatan, dan kemampuan untuk memberikan keyakinan, dan kehidupan serta kebebasan, keberhasilan, status, reputasi, pengakuan, penghargaan, dan perhatian. (5) Kebutuhan aktualisasi diri ialah kebutuhan guna mewujudkan diri sebagai seorang yang memiliki kemampuan yang unik (Wijono, 2015: 29-30).

Penulis menilai bahwa sertifikasi dosen ialah suatu kekuatan potensial yang ada di dalam diri setiap individu pegawai yang bisa dikembangkan sendiri atau dikembangkan oleh berbagai kekuatan luar yang pada intinya berkisar kompensasi semisal imbalan moneter yang bisa mengakibatkan hasil kerjanya secara positif atau secara negatif dimana tergantung pada keadaan yang dihadapi orang yang bersangkutan.

Dari hasil studi ini bisa diutarakan bahwa sertifikasi dosen mempunyai peranan yang penting untuk meningkatkan produktivitas kerja dosen IAIN Syekh Nurjati Cirebon. Dari hasil analisis data menunjukkan bahwa terdapat hubungan gaya kepemimpinan dan sertifikasi dosen dengan produktivitas kerja dosen IAIN Syekh Nurjati Cirebon. Apabila ditinjau dari hasil $\mathrm{f}$ test dan probabilitas gaya kepemimpinan dan sertifikasi dosen mempunyai hubungan signifikan dengan produktivitas kerja dosen IAIN Syekh Nurjati Cirebon. Oleh karena itu, 
bisa disimpulkan bahwa makin besar/tinggi hubungan gaya kepemimpinan dan sertifikasi dosen, maka makin besar/tinggi pula produktivitas kerja dosen IAIN Syekh Nurjati Cirebon.

Faktanya secara empiris, tinggi rendahnya produktivitas kerja dipengaruhi oleh sejumlah faktor, mulai dari disiplin (Elqadri, et al, 2015: 59), sikap sampai pada teknologi (Cascio dan Montealegre, 2016: 349-375; Niri, 2017: 1-4) dan manajemen (Iona, et al, 2008:1-28). Produktivitas kerja harus ditingkatkan melalui manajemen yang terpadu meliputi pendidikan, latihan (Khan dan Abdullah, 2019: 37-45), perbaikan sistem, dan pembentukan sikap mental (Bubonya, et al, 2017: 150-165; Westover, et al, 2010: 372-387). Pengetahuan dan ketrampilan pada hakekatnya adalah yang mendasari pencapaian produktivitas kerja. Konsep pengetahuan lebih mengarah kepada luas sempitnya wawasan yang dimiliki seseorang, penguasaan ilmu, daya pikir, dan inteligensi. Oleh karena itu, pengetahuan ialah akumulasi hasil proses pendidikan baik yang didapatkan secara formal, in formal ataupun non formal yang berkontribusi pada seseorang di dalam daya cipta, memecahkan masalah, termasuk dalam menyelesaikan tugas dan pekerjaan. Melalui pendidikan tinggi dan pengetahuan yang luas, seseorang pegawai diharapkan dapat melaksanakan pekerjaan dengan produktif dan baik.

Ketrampilan ialah penguasaan dan kemampuan teknis operasional tentang bidang tertentu, yang bersifat kekaryaan. Ketrampilan didapatkan melalui proses belajar dan berlatih. Ketrampilan berhubungan dengan kompetensi seseorang untuk melaksanakan dan menyelesaikan tugas dan pekerjaan yang bersifat teknis, seperti ketrampilan bengkel, ketrampilan komputer, dan sebagainya. Melalui ketrampilan yang dimiliki seseorang diharapkan dapat melaksanakan pekerjaan secara produktif. Kemampuan terbangun dari banyak kompetensi yang dimiliki oleh seorang pegawai. Ketrampilan dan pengetahuan termasuk faktor pembangun kemampuan. Oleh karena itu, jika seseorang memiliki ketrampilan dan pengetahuan yang tinggi, maka ia dapat mempunyai yang tinggi pula.

Sikap adalah suatu kebiasaan yang terpolakan. Apabila kebiasaan yang terpolakan tersebut berimplikasi positif pada hubungannya dengan perilaku kerja seseorang, maka dapat menguntungkan. Makna dari penjelasan ini bahwa jika berbagai kebiasaan dosen ialah baik, maka hal tersebut bisa menjamin perilaku kerja yang baik pula. Umpamanya seorang dosen memiliki kebiasaan disiplin dan tepat waktu, maka perilaku kerja juga baik, jika diberi tanggungjawab akan menepati kesepakatan dan aturan. Oleh karena itu, perilaku manusia juga akan dipastikan oleh berbagai kebiasaan yang tertanam dalam diri dosen sehingga bisa mendukung kerja yang efektif atau malah sebaliknya. Dengan keadaan dosen tersebut, maka produktivitas kerja bisa dipastikan bisa terealisasikan.

Pendidikan menambah dan membentuk pengetahuan seseorang untuk melakukan pekerjaan dengan lebih tepat dan cepat, 
sedangkan latihan meningkatkan dan membentuk ketrampilan kerja. Semakin tinggi tingkat latihan dan pendidikan seseorang, semakin tinggi juga taraf produktivitas kerjanya. Rendahnya taraf pendidikan sekarang ini di berbagai wilayah Tanah Air ini adalah suatu petunjuk rendahnya produktivitas kerja angkatan kerja. Oleh karena itu, peningkatan mutu pendidikan dan sejumlah program latihan kerja adalah suatu kebutuhan yang sangat urgen. Seseorang yang memiliki taraf pendidikan yang tinggi menjadikannya untuk berkarya lebih produktif daripada orang lain yang taraf pendidikannya rendah. Hal ini disebabkan orang yang berpendidikan tinggi mempunyai pandangan atau cakrawala yang luas sehingga dapat bekerja atau memperoleh lapangan kerja.

Hasil penelitian ini sejalan dengan pendapat Cohen (Sastropoetro, 1986: 122123), karena adanya peran serta individu dalam suatu program dikarenakan empat faktor, yaitu: (1) dari segi dasarnya, yakni partisipasi sebab desakan (impetus) dan partisipasi sebab adanya insentif. (2) Segi bentuk, yakni peran aktif terjadi secara terorganisasi, terdapat pengarahan dari pimpinan kelompok, dan peran aktif yang dilaksanakan secara langsung oleh individu itu sendiri. (3) Segi keluasannya, yakni peran aktif terjadi dengan menambah kesibukan di luar dan dengan mengorbankan waktu guna kepentingan pribadinya. (4) Segi efektivitasnya, yakni dengan menjadi partisipan berharap dapat memberikan saran atau dedikasi yang tentunya pada akhirnya akan memberikan faedah terhadap dirinya.

Undang-Undang Guru dan Dosen menjelaskan bahwa guru yang sudah lolos uji sertifikasi dapat diberi tunjangan profesi sejumlah satu kali gaji pokok. Hal tersebut diantara usaha lain dari pemerintah, yakni untuk meningkatkan kesejahteraan dosen di lapangan, disamping itu guna meningkatkan motivasi dosen dalam bekerja, sehingga dari sini dapat meningkatkan produktifitas dan kerja dosen. Adanya sertifikasi ini memotivasi dosen untuk terus-menerus meningkatkan kinerjanya. Hal ini dipertegas dengan hasil analisis deskriptif yang memperlihatkan bahwa sertifikasi dosen berpengaruh terhadap kinerja termasuk dalam kategori sangat tinggi, yakni $\mathrm{R}$ sebesar 0,846 atau $\mathrm{R}$ di atas 0,05 .

Oleh karena itu, temuan penelitian menunjukkan bahwa gaya kepemimpinan seorang pemimpin dan sertifikasi dosen memiliki hubungan yang signifikan pada produktivitas kerja atau bisa dijelaskan bahwa guna mencapai produktivitas kerja yang besar/tinggi sangat diperlukan faktor gaya kepemimpinan dan sertifikasi dosen yang benar dan efektif.

\section{SIMPULAN DAN SARAN}

Simpulan

Terdapat hubungan positif dan signifikan antara gaya kepemimpinan dengan produktivitas kerja dosen IAIN Syekh Nurjati Cirebon. Oleh karena itu, penelitian ini berhasil mendukung praduga penulis bahwa semakin besar atau tinggi hubungan gaya 
kepemimpinan maka produktivitas kerja dosen juga semakin besar atau tinggi.

Terdapat hubungan positif signifikan antara sertifikasi dosen dengan produktivitas kerja dosen IAIN Syekh Nurjati Cirebon. Oleh karena itu, penelitian ini berhasil mendukung praduga penulis bahwa semakin besar atau tinggi hubungan motivasi kerja maka produktivitas kerja dosen juga semakin besar atau tinggi.

Terdapat hubungan positif signifikan antara variabel gaya kepemimpinan dan motivasi kerja dengan produktivitas kerja dosen IAIN Syekh Nurjati Cirebon. Oleh karena itu, penelitian ini berhasil mendukung praduga penulis bahwa semakin besar atau tinggi hubungan gaya kepemimpinan dan motivasi kerja maka produktivitas kerja dosen juga semakin besar atau tinggi. Tinggi rendahnya produktivitas kerja ternyata dipengaruhi oleh banyak faktor mulai dari sikap, disiplin sampai pada manajemen dan teknologi. Semakin tinggi tingkat pendidikan dan latihan seseorang, semakin tinggi pula tingkat produktivitas kerjanya.

Saran

Bagi rektor IAIN Syekh Nurjati diharapkan lebih memperhatikan situasi dan kondisi dalam menerapkan gaya kepemimpinan dan sertifikasi dosen sehingga dosen termotivasi untuk semakin produktif lagi dalam melaksanakan Tri Darma Pendidikan sehingga nantinya akan didapatkan output yang berkualitas dan berkompetensi tinggi dalam segala bidang yang akhirnya berimplikasi dengan terbentuk dan terciptanya masyarakat yang madani, maju dan modern.

DAFTAR PUSTAKA

Abba, Halilu Dahiru, Ijeoma B. Anumaka, Sofia Sol Gaite. (2016). Leadership practices and productivity of academic staff in polytechnics in Nigeria. American Journal of Academic Research, 1 (2), 56-67.

Anoraga, Pandji. (2006). Pengantar pasar modal. Jakarta: Rineka Cipta.

Asvioa, Nova, Arpinus, Suharmon. (2017). The Influence of learning motivation and learning environment on undergraduate students' learning achievement of management of Islamic education, study program of IAIN Batusangkar In 2016. Noble International Journal of Social Sciences Research, 2 (2), 16-31.

Bubonya, Melisa, Deborah Ann Cobb-Clark, Mark Wooden. (2017). Mental health and productivity at work: does what you do matter? Labour Economics, 46, 150165.

Cakmak, Esra, Ozge Oztekin, and Engin Karadag. (2016). The effect of leadership on job satisfaction. Dalam E. Karadag (ed), Leadership and Organizational Outcomes: Metaanalysis of Empirical Studies, 2015. Switzerland: Springer International Publishing.

Cascio, Wayne F, dan Ramiro Montealegre. (2016). How technology is changing work and organizations. Annual Reviews of Organizational Psychology and Organizational Behavior, 3, 349375.

Elqadri, Zaenal Mustafa, Dewi Tri Wijayati Wardoyo \& Priyono. (2015). The influence of motivation and discipline work against employee work productivity Tona'an markets. Review of European Studies, 7, (12), 59-66. 
Hao, Moo Jun dan Rashad Yazdanifard. (2015). How effective leadership can facilitate change in organizations through improvement and innovation. Global Journal af Management and Business Research: a Administration and Management, 15, (9), 1-7.

Hardjana, André. (2006). Iklim organisasi: lingkungan kerja manusiawi. Jurnal Ilmu Komunikasi, 3, (1), 1-36.

Iona, Alfonsina, Peer-Olaf Siebers, Uwe Aickelin, Guiliana Battisti. (2008). Enhancing productivity: the role of management practices. SSRN Electronic Journal, 62, 1-28.

Iqbal, Anwar S, dan Haider N. (2015). Effect of leadership style on employee performance. Arabian Journal of Business and Management Review, 5, (5), 1-6.

Karyana. (2012). Pengaruh iklim organisasi terhadap produktivitas kerja. Jurnal Organisasi dan Manajemen, 8, (1), 6783.

Khan, Shahzad, Muhammad Asghar, Arshad Zaheer. (2014). Influence of leadership style on employee job satisfaction and firm financial performance: a study of banking sector in Islamabad, Pakistan. Actual Problems of Economics, 5 (155), 374-384.

Khan, Sohail Imran dan Nabaz Nawzad Abdullah. (2019). The impact of staff training and development on teacher's productivity. Economic, Management and Sustainability, 4 (1), 37-45.

Kodikal, Rashmi dan Sucharitha Suresh. (2015). Managerial skills and job satisfaction: a study among nurses in Healthcare Sector. ZENITH International Journal of Business Economics \& Management Research, 5 (6), 287-299.

Kodri, Irfa, Heni Fitriani, Ika Juliantina. (2018). Analisis pengaruh pelatihan dan sertifikasi terhadap produktivitas pekerja. Media Komunikasi Teknik Sipil, 24(1), 9-19.

Kurniawan, Asep. (2018). Metodologi penelitian pendidikan. Bandung: Remaja Rosdakarya.

Luthra, Anchal, dan Richa Dahiya. (2015). Effective leadership is all about communicating effectively: connecting leadership and communication. IJMBS, 5 (3), 43-48.

Mahayreh, Mohammad al-, Yanal Mahmoud Kilani, Faraj Abdullah Harahsheh. (2016). The influence of the leadership style on managerial creativeness from the perspective of employees within Jordanian Industrial Corporations. International Business and Management, 13, (3), 27-39.

Marques, Joan. (2010). Enhancing the quality of organizational communication: A presentation of reflection-based criteria," Journal of Communication Management, 14 (1), 47-58.

Muhardi, Arinto Nurcahyono. (2011). Pengaruh tunjangan sertifikasi terhadap produktivitas dosen dalam menghasilkan karya ilmiah dan penelitian. Prosiding Seminar Nasional Penelitian dan PKM: Sosial, Ekonomi, dan Humaniora, 99-105.

Niri, Anwer AM. (2017). The impact of technology factors on the workers' productivity an empirical study on $\mathrm{Al}$ Borg Cement Factory in Libya. International Journal of Economics \& Management Sciences, 6 (4), 1-4.

Nulhaqim, Soni Akhmad, R. Dudy Heryadi, Ramadhan Pancasilawan, Muhammad Fedryansyah. (2016). Peranan perguruan tinggi dalam meningkatkan kualitas pendidikan di Indonesia untuk menghadapi ASEAN Community 2015: studi kasus: Universitas Indonesia, Universitas Padjadjaran, Institut Teknologi Bandung. Share: Social Work Jurnal, 6 (2), 154-272. 
Odine, Maurice. (2015). Communication problems in management. Journal of Emerging Issues in Economics, Finance and Banking (JEIEFB), 4, (2), 16151630 .

Oppong, Akua Ahyia Adu-, \& Emmanuel Agyin-Birikorang. (2014). Communication in the workplace: guidlines for improving effectiveness. Global Journal of Commerce \& Management Perspective, 3, (5), 208213.

Purwanto. (2015). Pengaruh kepemimpinan terhadap kinerja dosen di perguruan tinggi. Jurnal Manajemen, 14, (1), 4758.

Rahzianta, Muhammad Luthfi Hidayat. (2016). Pembelajaran sains model service learning sebagai upaya pembentukan habits of mind dan penguasaan keterampilan berpikir inventif. Unnes Science Education Journal, 5, (1), 1128-1137.

Raju, R. Satya, dan A. Parthasarathy. (2009). Management. New Delhi: Private Limited.

Sadeli, Jimmy. (2012). The influence of leadership, talent management, organizational cultureand organizational support on employee engagement. International Research Journal of Business Studies, 5, (3), 1-21.

Sastropoetro, Santoso. (1986). Komunikasi sosial. Bandung: Remaja Rosda Karya.

Seyedinejat, Seyedeh Sahar, Mohammad Ebrahim Razaghi, Morteza Dousti. (2014). Prioritizing managerial skills based on Katz's Theory. Pamukkale Journal of Sport Sciences, 5, (1), 33-47.

Soetrisno, Edy. (2017). Manajemen sumber daya manusia. Jakarta: Kencana.

Sokoli, Dugagjin. (2017). Qualification of lecturers as indicator of quality teaching in higher education. Conference: MakeLearn \& TIIM 2017, At Lublin, Poland, 445-451.
Soliha, Euis dan Hersugondo. (2008). Kepemimpinan yang efektif dan perubahan organisasi. Fokus Ekonomi, 7, (2), 83-93.

Surji, Kemal M., (2014). The positive affect of leadership on employee performance and its impact on improving workplace environment in addition to organizational culture. European Journal of Business and Management, 6, (25), 105-161.

Tahrir. (2010). Hubungan kompetensi dan disiplin kerja dosen terhadap motivasi belajar mahasiswa. Psympathic: Jurnal Ilmiah Psikologi, 3, (2), 145-156.

Taştan, Seçil Bal, Seyed Mehdi Mousavi Davoudi, Alfiya R. Masalimova, Alexandr S. Bersanov, Rashad A. Kurbanov, Anna V. Boiarchuk, Andrey A. Pavlushin. (2018). The impacts of teacher's efficacy and motivation on student's academic achievement in science education among secondary and high school students. EURASIA Journal of Mathematics, Science and Technology Education, 14 (6), 23532366.

Thoha, Miftah. (2013). Kepemimpinan dalam manajemen. Jakarta: RajaGrafindo.

Thomas, Gail Fann. (2009). The central role of communication in developing trust and its effect on employee involvement. Journal of Business Communication, 46 (3), 287-310.

Westover, Jonathan, Andrew R. Westover, dan L. Alan Westover, (2010). Enhancing long-term worker productivity and performance. International Journal of Productivity and Performance Management, 59(4), 372-387.

Wijono, Sutarto. (2015). Psikologi industri dan organisasi dalam suatu bidang gerak psikologi sumber daya manusia. Jakarta: Kencana.

Vischer, Jacqueline. (2007). The effects of the physical environment on job 
performance: towards a theoretical model of workspace stress. Stress and Health, 23(3), 175-184. 